\title{
PAPP-A in normal human mesangial cells: effect of inflammation and factors related to diabetic nephropathy
}

\author{
Diane Donegan, Laurie K Bale and Cheryl A Conover \\ Division of Endocrinology, Diabetes, Metabolism and Nutrition, Mayo Clinic, Rochester, Minnesota, USA
}

Correspondence should be addressed to C A Conover Email

Conover@mayo.edu

\begin{abstract}
Insulin-like growth factors (IGFs) are implicated in the development of diabetic nephropathy (DN) and are shown to increase proliferation and extracellular matrix production in mesangial cells. The IGF system is complex and is composed of ligands, receptors, six binding proteins (IGF BPs) and a novel zinc metalloproteinase - pregnancyassociated plasma protein (PAPP)-A. PAPP-A increases the local bioavailability of IGF through the cleavage of IGF BP-4. Mesangial expansion is a major component of DN, and PAPP-A is shown to be increased in the glomeruli of patients with DN. Therefore, we determined the expression of PAPP-A and components of the IGF system in normal human mesangial cells (HMCs) and their regulation by factors known to be involved in DN. Under basal conditions, HMCs expressed PAPP-A, IGF1 receptor and all six IGF BPs. Interleukin (IL)- $1 \beta$ was the most potent stimulus for PAPP-A expression (5-fold) followed by tumor necrosis factor (TNF)- $\alpha$ (2.5-fold). This PAPP-A was secreted, cell associated and proteolytically active. IL1 $\beta$ also increased IGF BP-1expression (3-fold) with either reduction or no effect on other IGF BPs. Generally, TNF- $\alpha$ treatment decreased IGF BP expression. No treatment effect on PAPP-A or IGF BPs was seen with IL6, IGFs, advanced glycation end products or prolonged hyperglycemia. In addition, stimulation of HMCs with IGF1 alone or IGF1 complexed to wild-type, but not protease-resistant, IGF BP-4 led to increased $\left[{ }^{3} \mathrm{H}\right]$-thymidine incorporation. In conclusion, these novel findings of PAPP-A and its regulation by proinflammatory cytokines, as well as the comprehensive analysis of the IGF system regulation in HMCs, suggest a mechanism by which inflammatory

states such as DN can impact IGF activity in the kidney.
\end{abstract}

Journal of Endocrinology (2016) 231, 71-80

\section{Introduction}

Diabetic nephropathy (DN) is the leading cause of endstage renal disease worldwide (ADA 2014), accounting for nearly half of all causes of renal failure despite the currently available therapy. It is characterized by glomerular hyperfiltration, basement membrane thickening and mesangial expansion with eventual

\section{Key Words}

- pregnancy-associated plasma protein-A

- insulin-like growth factor

- human mesangial cells

- diabetic nephropathy glomerular sclerosis (Mauer et al. 1984, Tervaert et al. 2010) and tubular interstitial fibrosis (Mauer et al. 1984, Fioretto \& Mauer 2007, Tervaert et al. 2010). Mesangial expansion is thought to be an important component in the development of DN and has shown the strongest correlation with the clinical manifestations of $\mathrm{DN}$ 
(Steffes et al. 1989, An et al. 2015). Therefore, identification of factors involved in the pathophysiology of mesangial expansion that could be targeted therapeutically in DN is of great interest.

Insulin-like growth factors (IGFs) not only play a role in the development of kidney (Hirschberg \& Adler 1998), but also have been implicated in the pathogenesis of DN (Kamenicky et al. 2014). Several cellular subtypes have been implicated in the development of DN including the mesangial cell (Abboud 2012, Maezawa et al. 2015). Indeed, stimulation of human mesangial cells with IGF1 or IGF2 is shown to increase the synthesis of extracellular matrix proteins in a dose-dependent manner (Steffes et al. 1989, Feld et al. 1995, Pricci et al. 1996) or lead to mesangial cell proliferation (Schreiber et al. 1995), suggesting a role for IGFs in the development of DN involving mesangial cells.

To better understand this role, it is important to take into account the complexity of the IGF system. It includes not only IGF ligands and transmembrane intracellular signaling receptors but also six high-affinity IGF-binding proteins (BPs) that can modulate IGF interactions with the IGF1 receptor (IGF1R). In addition, pregnancy-associated plasma protein (PAPP)-A, a cell membrane-associated zinc metalloprotease, regulates the local bioavailability of IGF for IGF1R activation by cleaving inhibitory IGF BP-4 to which the IGF is bound (Lawrence et al. 1999, Boldt $\&$ Conover 2007). Thus, PAPP-A adds a further layer of complexity to the IGF system and has demonstrated its involvement in several degenerative diseases of age (Conover et al. 2010, Bale et al. 2014, Harstad \& Conover 2014). In a recent study, PAPP-A expression was found to be increased in glomeruli of patients with DN compared with that in healthy controls. Moreover, PAPP-A knockout mice with streptozotocin (STZ)-induced diabetes were resistant to the development of hyperglycemia-induced DN and mesangial expansion compared with STZ-induced diabetic wild-type mice (Mader et al. 2013).

In this study, we determined PAPP-A expression in normal human mesangial cells and its regulation by factors known to be involved in DN (proinflammatory cytokines, growth factors and hyperglycemia). In addition, we determined IGF, IGF BP-1to BP-6 and IGF1R expression to allow interactive modeling of regulatory mechanisms for local glomerular IGF bioavailability in DN.

\section{Materials and methods}

\section{Reagents}

Tumor necrosis factor (TNF)- $\alpha$ was purchased from Life Technologies. Interleukin (IL)-1 $\beta$, IL6, transforming growth factor (TGF)- $\beta$, IGF1 and IGF2 were purchased from R\&D Systems. Reagents for SDS-PAGE, mini-gels and blocking buffer were purchased from Bio-Rad Laboratories. Mannitol and D-glucose were purchased from SigmaAldrich. Advanced glycation end products (AGE), AGE

Table 1 Real-time PCR primers.

\begin{tabular}{|c|c|c|c|}
\hline Gene & NCBI accession number & Primer sequence $5^{\prime}-3^{\prime}$ & Size (bp) \\
\hline \multirow[t]{2}{*}{ PAPP-A } & NM_002581.3 & Forward: TGACCGTGCGTGACATCCC & 177 \\
\hline & & Reverse: GCAAAAGGCTCGGTTGTTGAT & \\
\hline \multirow[t]{2}{*}{ IGF BP-1 } & NM_000596 & Forward: TTCCATCCTTTGGGACGCCAT & 125 \\
\hline & & Reverse: CCTTGGCTAAACTCTCTACGACT & \\
\hline \multirow[t]{2}{*}{ IGF BP-2 } & NM_000597.2 & Forward: TGCAGACAATGGCGATGACC & 150 \\
\hline & & Reverse: GTGACCTTCTCCCGGAACAC & \\
\hline \multirow[t]{2}{*}{ IGF BP-3 } & NM_001013398.1 & Forward: ACCTGAAGTTCCTCAATGTGC & 144 \\
\hline & & Reverse: GCTGCCCATACTTATCCACAC & \\
\hline \multirow[t]{2}{*}{ IGF BP-4 } & NM_001552.2 & Forward: CGCAACGGCAACTTCCACC & 168 \\
\hline & & Reverse: CAGGCCTCACTCTCGAAAGC & \\
\hline \multirow[t]{2}{*}{ IGF BP-5 } & NM_000599.3 & Forward: CTTCAGATTCCGAGTTGCCTAC & 100 \\
\hline & & Reverse: AATATGTACTGTGGTTATTGCTGTCTTC & \\
\hline \multirow[t]{2}{*}{ IGF BP-6 } & NM_002178 & Forward: ATGTGAACCGCAGAGACCAAC & 159 \\
\hline & & Reverse: TTTGAGCCCCTCGGTAGACCT & \\
\hline \multirow[t]{2}{*}{ RPI-19 } & NM_000981.3 & Forward: GCAGGCACATGGGCATAGGTA & 203 \\
\hline & & Reverse: TTCCATGAGAATCCGCTTGTT & \\
\hline \multirow[t]{2}{*}{ IGF1 } & NM_001111283.1 & Forward: AGCAGTCTTCCAACCCAAT & 240 \\
\hline & & Reverse: CCGACTGCTGGAGCCATAC & \\
\hline \multirow[t]{2}{*}{ IGF2 } & NM_000612 & Forward: GCCAAAGTCCCGCTAAGATTC & 53 \\
\hline & & Reverse: GGAGCGGGGCTCAGACCATGA & \\
\hline \multirow[t]{2}{*}{ IGF1R } & NM_000875.3 & Forward: CCCAAATTATGTGTTTCCGAAAT & 174 \\
\hline & & Reverse: CCAGGTTATGATGATGCGATTCT & \\
\hline $\begin{array}{l}\text { http://joc } \\
\text { DOI: } 10 .\end{array}$ & $\begin{array}{r}\text { (๑) } 2016 \text { Societ } \\
\text { Prin }\end{array}$ & d by Bioscientifica Ltd. & \\
\hline
\end{tabular}


Table 2 Human mesangial cell mRNA expression and protein production of IGF system components under serum-free conditions.

\begin{tabular}{|c|c|c|}
\hline & 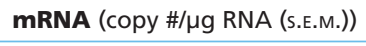 & Protein $(\mathrm{ng} / \mathrm{mL}) *$ \\
\hline PAPP-A & $1.20 \times 10^{7}\left(2.84 \times 10^{6}\right)$ & 12.5 \\
\hline IGF1R & $4.74 \times 10^{6}\left(1.06 \times 10^{5}\right)$ & UK \\
\hline IGF1 & ND & ND \\
\hline IGF2 & $2.71 \times 10^{6}\left(1.47 \times 10^{6}\right)$ & ND \\
\hline IGF BP-1 & $1.32 \times 10^{5}\left(1.42 \times 10^{4}\right)$ & 0.2 \\
\hline IGF BP-2 & $1.59 \times 10^{4}\left(2.17 \times 10^{3}\right)$ & UK \\
\hline IGF BP-3 & $2.57 \times 10^{8}\left(2.39 \times 10^{7}\right)$ & 158 \\
\hline IGF BP-4 & $2.98 \times 10^{5}\left(4.14 \times 10^{4}\right)$ & 70 \\
\hline IGF BP-5 & $4.52 \times 10^{8}\left(1.07 \times 10^{8}\right)$ & 1300 \\
\hline IGF BP-6 & $2.21 \times 10^{7}\left(4.34 \times 10^{6}\right)$ & 7 \\
\hline
\end{tabular}

ND, not detected; UK, unknown.

$N=4$. *Performed in duplicate.

control and bovine serum albumin (BSA) were purchased from Biovision. Wild-type and protease-resistant IGF BP-4 were kindly provided by Dr C Oxvig (Aarhus University, Aarhus, Denmark). $\left[{ }^{3} \mathrm{H}\right]$-Thymidine was purchased from Perkin-Elmer.

\section{Cell culture}

Normal human mesangial cells (NHMs) were purchased from Lonza (Walkersville, MD, USA; catalog number: CC-2559) and cultured in the recommended basal media (MsBM containing $5 \mathrm{mM}$ glucose) with 5\% fetal bovine serum (FBS) as per supplier's recommendations. Routine characterization of NHMs at Lonza includes immunofluorescent staining. The cells stained positive for fibronectin and negative for von Willebrand (Factor VII) antigen. The cells of $4-14$ th passage were used for experiments, which were performed in triplicate and
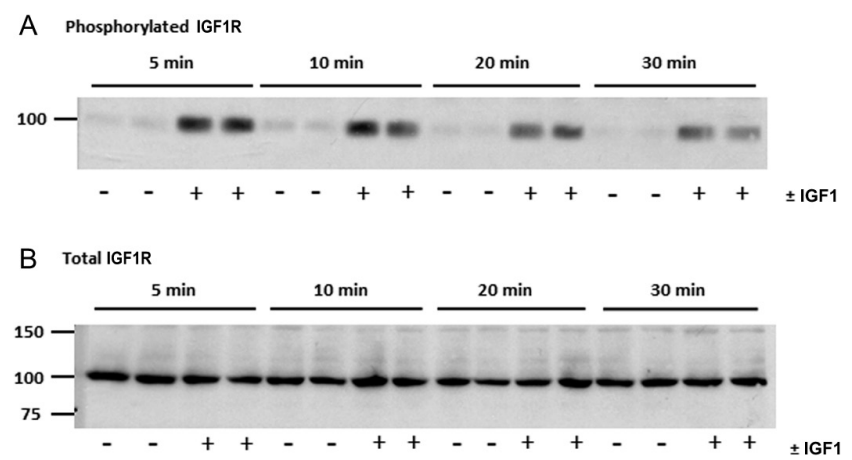

Figure 1

Western blot for (A) phosphorylated IGF1R and (B) total IGF1R with or without IGF1 stimulation for specified times. One experiment; samples in duplicate. Positions of molecular size markers are indicated on the left. repeated 3-4times. Before each experiment, cells were washed twice with phosphate-buffered saline (PBS) and then changed to serum-free media containing $0.1 \%$ bovine serum albumin (SFM), except for TNF- $\alpha$ where $2 \%$ FBS was used, with and without experimental additions. On completion of incubation, conditioned media were collected and stored at $-80^{\circ}$. Cells were lysed for real-time PCR or membrane preparation.

\section{Real-time PCR}

The cells were lysed with TRIzol (Life Technologies), and total RNA was isolated. One microgram of RNA was reverse transcribed with the SuperScript III First-Strand Synthesis System (Life Technologies), and mRNA expression was evaluated by quantitative real-time PCR using the iCycler iQ5 Detection System with iQ SYBR green PCR Master Mix (Bio-Rad). Amplification plots were analyzed with iQ5 Optical System Software version 2.1 (Bio-Rad). The primer sequences for PAPP-A, IGF1, IGF2, IGF1R, IGF BP-1 to -6 and RPL-19 reference gene are shown in Table 1.

\section{Membrane preparation}

Human mesangial cell membranes were isolated as described previously (Conover et al. 2007). Briefly, after $72 \mathrm{~h}$ of culture, HMCs were washed twice in cold PBS and lysed in cold RIPA buffer $(0.15 \mathrm{~N} \mathrm{NaCl}, 0.5 \%$ Nonidet P-40, $0.1 \%$ SDS, $50 \mathrm{~mm}$ Tris, pH 7.6) and phenomethylsulfonyl fluoride (PMSF). After placing on ice for $30 \mathrm{~min}$, the cell lysate was centrifuged at $100 \boldsymbol{g}$ for $5 \mathrm{~min}$. The supernatant was centrifuged at $6800 \boldsymbol{g}$ for $20 \mathrm{~min}$. The resultant supernatant fraction was further centrifuged for $60 \mathrm{~min}$ at $222,600 \boldsymbol{g}$ in a Beckman Ultracentrifuge (Beckman Instruments, Brea, CA, USA). The membrane pellet was then suspended in RIPA buffer and PMSF and stored at $-80^{\circ} \mathrm{F}$ before use in experiments.

\section{ELISA}

Conditioned media levels of PAPP-A, IGF BP-3, -4 and -5, and IGF1 and 2 proteins were quantified using enzymelinked immunosorbent assays (ELISAs) kindly provided by Ansh Labs (Webster, TX, USA). The PAPP-A ELISA is an ultrasensitive picoPAPP-A. Standards for IGF1 and IGF2 ELISAs were diluted for increased sensitivity. IGF BP-1 and - 6 were quantified by ELISA kits purchased from Abcam. All assays were performed in accordance with manufacturer's instructions.

Published by Bioscientifica Ltd 


\section{IGF BP-4 protease assay}

PAPP-A-mediated IGF BP-4 proteolysis was assayed, as described previously (Conover et al. 1993, Durham et al. 1994). Conditioned media or membrane preparations were incubated at $37^{\circ}$ for the indicated times with ${ }^{125}$ I-IGF BP-4 with or without 5 nM IGF2 (IGF BP-4 needs to bind IGF for cleavage by PAPP-A (Conover et al. 1993)). In some experiments, samples were incubated at $37^{\circ}$ with or without immunoneutralizing PAPP-A monoclonal antibody (mAbPAPP-A, (Mikkelsen et al. 2014)) for $1 \mathrm{~h}$ before the addition of ${ }^{125} \mathrm{I}-\mathrm{IGF}$ BP-4/IGF2. Reaction products were separated by SDS-PAGE and visualized by autoradiography. Western blots were quantified using ImageJ software (National Institutes of Health, Bethesda, MD, USA).

\section{IGF1R phosphorylation}

Cells were washed twice with PBS and made quiescent with SFM for $24 \mathrm{~h}$. Cells were then washed $\times 1$ with PBS and $S F M \pm 10 \mathrm{nM}$ of IGF1 was added for 5, 10 or $15 \mathrm{~min}$. After incubation with IGF1 for the aforementioned times, the cells were washed with cold PBS $\times 3$ and placed on ice. Then, the Cells were lysed in $60 \mu \mathrm{L}$ MPER (Thermo Fisher Scientific) and phosphate inhibitors ( $2 \mathrm{nM}$ sodium orthovanadate, $10 \mathrm{mM}$ sodium pyrophosphate, $40 \mathrm{mM}$ $\beta$-glycerol phosphate and $10 \mathrm{mM}$ of sodium fluoride, protease tablet) and sonicated for $5 \mathrm{~s}$. Under reducing conditions, $50 \mu \mathrm{L}$ sample was separated by $7.5-15 \%$ SDS-PAGE and transferred to polyvinyl difluoride. Filters were blocked with $5 \%$ nonfat milk in Tris-buffered saline with $0.1 \%$ Tween 20 (TBS-T), and then incubated overnight at $4^{\circ} \mathrm{C}$ with primary antibody (phosphorylated, 1:1000 (Pierce Thermo Scientific) and total IGF1R, 1:1000 (Novus Biologicals, Littleton, CO, USA)). Membranes were then washed three times for $5 \mathrm{~min}$ in TBS-T and incubated with secondary antibody with a streptavidinHRP conjugate and chemiluminescent substrate (Pierce) for detection.

\section{$\left[{ }^{3} \mathrm{H}\right]$-thymidine incorporation}

Human mesangial cell monolayers were incubated in SFM with IL1 $\beta$ ( $1 \mathrm{nM})$ for $48 \mathrm{~h}$ to increase PAPP-A expression/ secretion. Wild-type or protease-resistant IGF BP-4 (4 mM) was precomplexed with IGF-1 (4nM) and then added to the conditioned media. $\left[{ }^{3} \mathrm{H}\right]$-Thymidine incorporation (8-48 $\mathrm{h}$ after the addition of IGF BP-4/IGF-1) into acidprecipitable material was measured as described previously (Ortiz et al. 2003).

\section{Statistical analysis}

Results are expressed as mean \pm s.E.M. for the indicated number of experiments. The appropriate comparative controls were used in each independent experiment. Relative expression compared with control was assessed using a one-sample $t$-test. For multiple comparisons to a single control in the $\left[{ }^{3} \mathrm{H}\right]$-thymidine incorporation assay and protease assays, ANOVA and Dunnett's test were used. Significance was set at $P<0.05$.
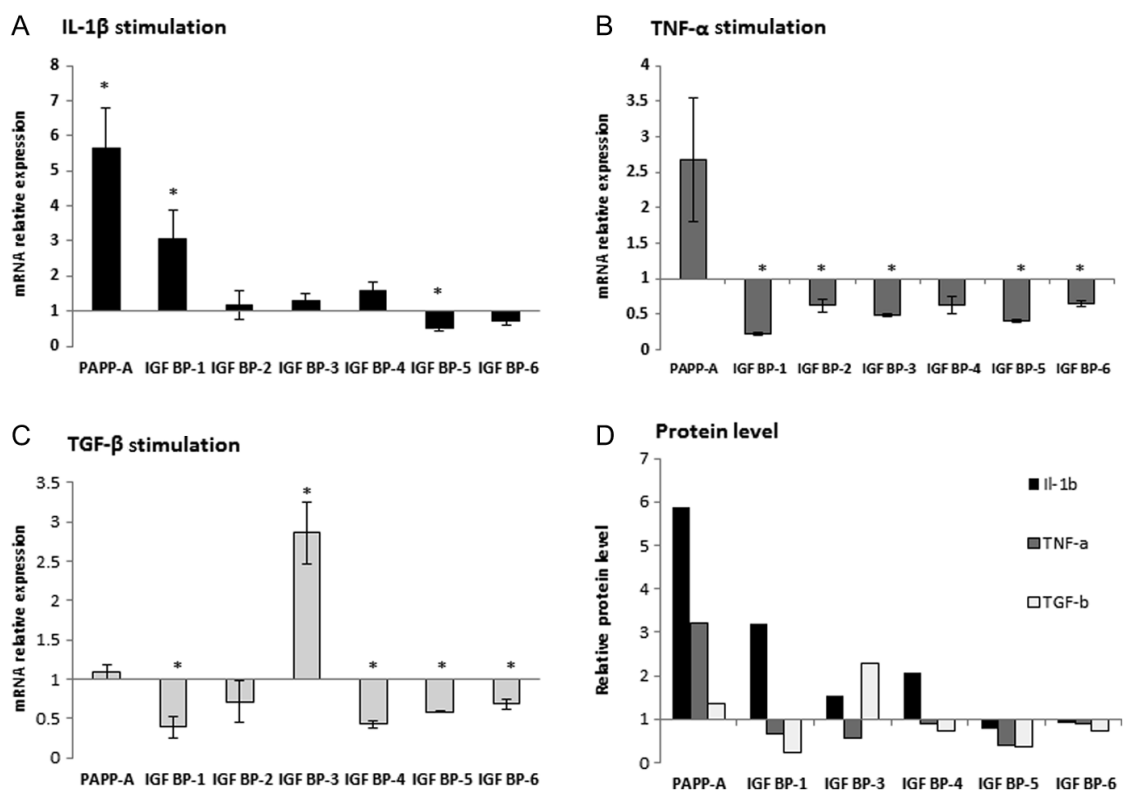

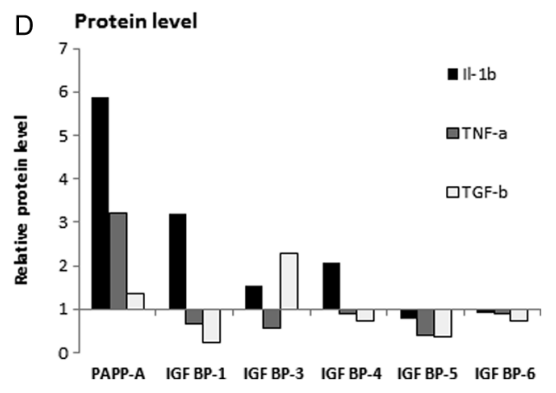

Figure 2

Relative mRNA expression following (A) IL1 $\beta$ $(1 \mathrm{nM}),(B)$ TNF- $\alpha(1 \mathrm{nM})$ or (C) TGF- $\beta(10 \mathrm{ng} / \mathrm{mL})$ exposure for $24 \mathrm{~h}$ as determined by RT-PCR (mean + S.E.M., $N=3-4$ separate experiments; $\star P<0.05)$ and $(D)$ protein levels after exposure for $72 \mathrm{~h}$ as determined by ELISA.
() 2016 Society for Endocrinology Printed in Great Britain 


\section{Results}

\section{Basal expression of IGF system components in HMCs}

First, we established expression levels of PAPP-A and other IGF system components in HMCs under unstimulated culture conditions (Table 2). HMCs expressed relatively high mRNA levels for PAPP-A, IGF1R, IGF2 and all six IGF BPs. IGF1 mRNA was not detected.

To determine if mRNA expression translated into protein production, 72-h HMC-conditioned media were analyzed using specific ELISAs for PAPP-A, IGF1, IGF2 and IGF BPs. Except for IGF2, protein levels in conditioned media mirrored mRNA expression. PAPP-A and IGF BP-1, $-3,-4$ and -5 were detected in control media, and IGF1 and 2 were not detected. It is of note that PAPP-A protein levels in the media seem low compared with the high mRNA expression levels. However, secreted PAPP-A binds to the surface of the secreting (and neighboring) cells, serving an autocrine/paracrine function (Laursen et al. 2002, Conover et al. 2007). Indeed, we found very high levels of PAPP-A protein when assaying HMC membrane preparations (138 ng/ng protein). IGF BP-1 was also detected in membrane preparations suggesting cell surface localization (5 ng/ng of protein).

Although normal HMCs in culture do not secrete appreciable IGFs, they do express IGF1R. To determine if HMCs are responsive to IGF1, IGF1R phosphorylation, a direct measure of activation, was assessed using Western blot. The addition of $10 \mathrm{ng} / \mathrm{mL}$ IGF1 resulted in marked increases in IGF1R phosphorylation within $5 \mathrm{~min}$ (Fig. 1). There was no change in total IGF1R.

\section{Regulation of PAPP-A expression in HMCs}

Factors associated with the development of DN, including inflammatory cytokines (interleukin (IL)- $1 \beta$, IL6, tumor necrosis factor (TNF)- $\alpha$ ), growth factors (transforming growth factor (TGF)- $\beta$, IGF1, IGF2), hyperglycemia and advanced glycation end products (AGE), were assessed to determine their impact on PAPP-A expression in HMCs. The effects of stimulation with IL- $1 \beta(1 \mathrm{nM})$, TNF- $\alpha(1 \mathrm{nM})$ and TGF- $\beta$ $(10 \mathrm{ng} / \mathrm{mL})$ for $24 \mathrm{~h}$ are summarized in Fig. 2. IL-1 $\beta$ was the most potent stimulator of PAPP-A expression. A greater than five-fold increase in PAPP-A mRNA expression compared with control was seen with IL1 $\beta$ treatment. Relative expression of PAPP-A mRNA increased $\sim 2.5$-fold with TNF- $\alpha$ treatment, but this did not reach statistical significance. No change was seen with TGF- $\beta$ treatment. IGF1 (10 nM), IGF2 (10 nM), IL6 $(50 \mathrm{ng} / \mathrm{mL}), \operatorname{AGE}(50,100$ or $200 \mu \mathrm{g})$ or hyperglycemia (25 mM vs $5 \mathrm{mM}$ ) did not affect PAPP-A mRNA expression, even after prolonged exposure (up to 4 weeks) with the latter (results not shown).

To determine if PAPP-A secreted by HMCs is proteolytically active, an IGF-dependent IGF BP-4 protease assay was performed on cell-conditioned media. Its biologic activity was confirmed with the addition of IGF2 (Fig. 3). In the absence of IGF2, IGF BP-4 was not cleaved, supporting the absence of endogenous IGF1 and 2 in the media, both of which bind to IGF BP-4. In the presence of exogenous IGF2, IGF BP-4 cleavage was observed. This IGF-dependent IGF BP-4 proteolysis was increased with IL-1 $\beta$ (1.7-fold, $P=0.008)$ and TNF- $\alpha$ (1.9-fold, $P=0.02$ ), but not TGF- $\beta$ or AGE, consistent with both ELISA and real-time PCR findings. TNF- $\alpha$ treatment also increased IGF-dependent IGF BP-4 proteolysis in cell-conditioned media. High glucose did not increase IGF-dependent IGF BP-4 proteolysis in cell conditioned media (data not shown).

Cell surface localization of PAPP-A is thought to be a mechanism by which PAPP-A can serve to enhance local IGF1 action (Laursen et al. 2002, Conover et al. 2007).

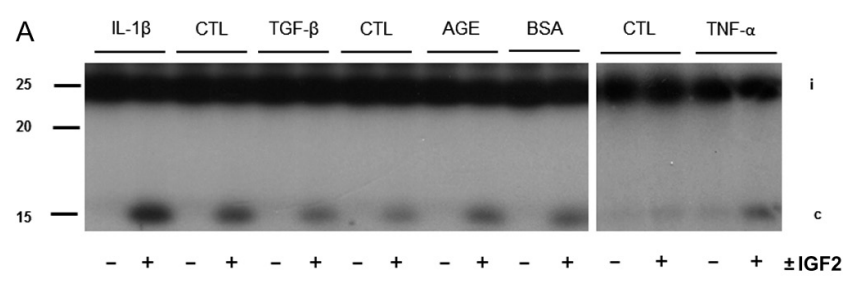

B

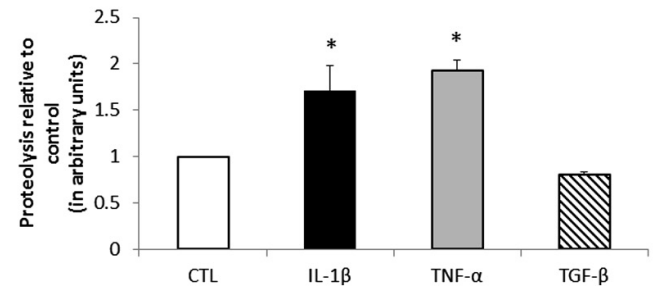

Figure 3

IGF BP-4 protease assay: (A) HMCs were incubated with SFM \pm IL-1 $\beta$ $(10 \mathrm{ng} / \mathrm{mL})$, TGF- $\beta(10 \mathrm{ng} / \mathrm{mL})$ or AGE $(200 \mu \mathrm{g})$ for $72 \mathrm{~h}$. ${ }^{125}$ /-IGF BP-4 without $(-)$ or with (+) $5 \mathrm{nM}$ of IGF2 was added to conditioned media for $6 \mathrm{~h}$, and products were separated by SDS-PAGE. Each intervention has a corresponding control; (B) fold change in IGF BP-4 proteolysis of intervention compared with control (mean +s.E.M., $N=3-4$ separate experiments; $\left.{ }^{*} P<0.05\right)$; $C T L$ : control, $\mathrm{i}=$ intact IGF BP-4; $\mathrm{c}=$ cleaved IGF BP-4. Positions of molecular size markers are indicated on the left.

Published by Bioscientifica Ltd 
To assess whether PAPP-A is cell membrane associated and proteolytically active in HMCs, the IGF BP-4 protease assay was performed on solubilized membrane protein (Fig. 4). Cleavage products of IGF BP-4 were detected in the presence of exogenous IGF2, and proteolysis was increased after IL1 $\beta$ (3.5-fold, $P \leq 0.001)$ and TNF- $\alpha$ (2.1-fold, $P=0.04$ ) stimulation. The proteolytic activity of PAPP-A can be inhibited by the addition of a monoclonal antibody targeted to a unique exosite in PAPP-A (mAb-PAPP-A) that specifically inhibits IGF BP-4 proteolysis (Mikkelsen et al. 2014). Therefore, to confirm that cleavage of IGF BP-4 was solely attributable to PAPP-A in HMCs, solubilized membrane proteins were incubated with inhibitory mAb-PAPP-A or isotype control and the protease assay was performed. Control

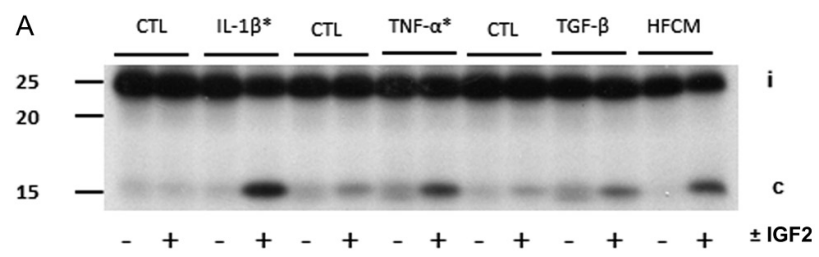

B
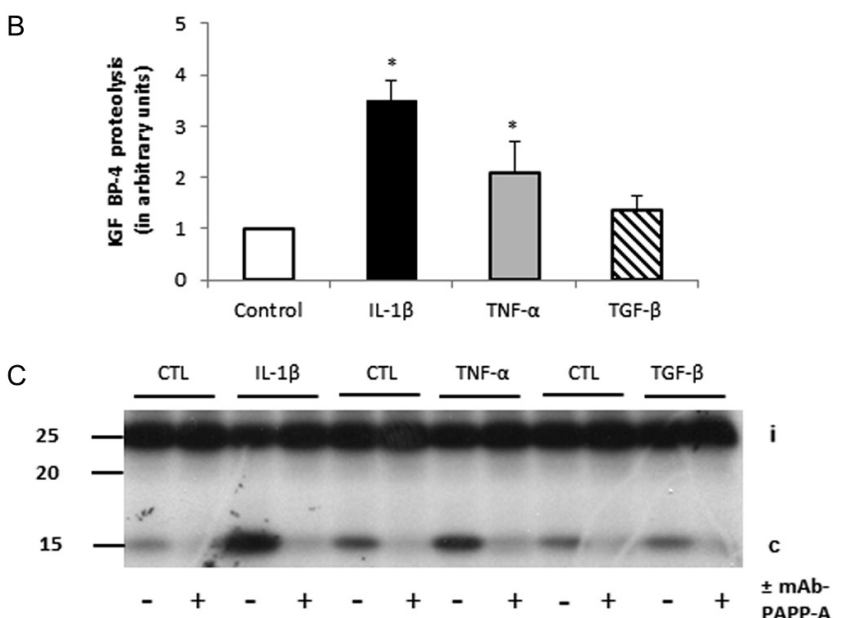

Figure 4

IGF BP-4 protease assay on solubilized membrane proteins: (A) HMCs were incubated with SFM $\pm \mathrm{IL}-1 \beta(10 \mathrm{ng} / \mathrm{mL}), \mathrm{TNF}-\alpha(1 \mathrm{nM})$ or TGF- $\beta(10 \mathrm{ng} / \mathrm{mL})$ for $72 \mathrm{~h}$. 125I-IGF BP-4 without (-) or with (+) $5 \mathrm{nM}$ of IGF2 was added to conditioned media for $6 \mathrm{~h}$, and the products were separated by SDS-PAGE. Each intervention has a corresponding control; (B) the relative fold change in IGF BP-4 proteolysis of intervention compared with control (mean+s.E.M., $N=3$ separate experiments; ${ }^{*} P<0.05$ ); (C) effect of PAPP-A inhibition. ${ }^{125}$ I-IGF BP-4 with $5 \mathrm{nM}$ of IGF2 was preincubated for $1 \mathrm{~h}$ for complex formation. This complex was then added to solubilized membrane proteins without (-) or with (+) mAb-PAPP-A (10-8 M) for $6 \mathrm{~h}$, and protease assay was performed. Each intervention has a corresponding control. CTL: control; i = intact IGF BP-4, c=cleaved IGF BP-4. HFCM: human fibroblast conditioned media (positive control for PAPP-A-mediated IGF BP-4 proteolysis). Positions of molecular size markers are indicated on the left. and stimulated proteolysis of IGF BP-4 was completely inhibited by mAb-PAPP-A (Fig. 4C).

\section{Regulation of IGF BP expression in HMCs}

IL1 $\beta$ treatment also had effects on IGF BP expression (Fig. 2A). In particular, IGF BP-1 mRNA was increased three-fold with IL-1 $\beta$, whereas IGF BP-5 mRNA was significantly inhibited. TNF- $\alpha$ treatment had general inhibitory effects on IGF BP expression, including IGF BP-1expression (Fig. 2B). TGF- $\beta$ treatment resulted in a general reduction in IGF BP expression, except for IGF BP-3, which increased 2.9-fold (Fig. 2C). No change in IGF BP expression was seen after stimulation with IGF1 or 2, IL6, AGE $(50,100$ and $200 \mu \mathrm{g})$ or high glucose (25 mM) compared with the control (data not shown). Protein levels of PAPP-A and IGF BP reflected mRNA expression (Fig. 2D).

\section{The effect of PAPP-A-regulated IGF BP-4 proteolysis on IGF1 stimulated $\left.{ }^{3} \mathrm{H}\right]$-thymidine incorporation in $\mathrm{HMCs}$}

HMCs were preincubated with IL1 $\beta$ so as to increase PAPP-A expression and production. The effect of IGF1 on $\left[{ }^{3} \mathrm{H}\right]$-thymidine incorporation in HMCs was then assessed. $\left[{ }^{3} \mathrm{H}\right]$-thymidine incorporation was significantly

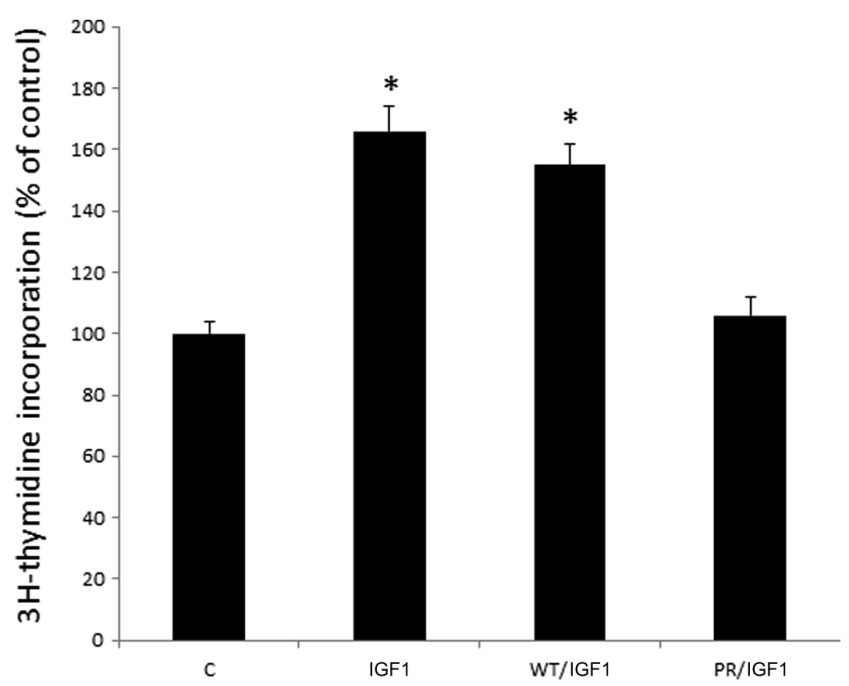

\section{Figure 5}

IGF1-stimulated [ $\left.{ }^{3} \mathrm{H}\right]$-thymidine incorporation. HMCs were first incubated with IL1 $\beta$ for $48 \mathrm{~h}$. Precomplexed wild-type (WT) or protease-resistant (PR) IGF BP-4/IGF1 was then added to the conditioned medium.

$\left[{ }^{3} \mathrm{H}\right]$-Thymidine incorporation is presented as percentage of control (mean + S.E.M., $N=3$ replicates; ${ }^{*} P=<0.05$ ). Similar findings were obtained in a separate experiment; i.e., WT IGF BP-4, susceptible to PAPP-Amediated proteolysis, but not PR IGF BP-4, allowed significant IGF1stimulated $\left[{ }^{3} \mathrm{H}\right]$-thymidine incorporation.

Published by Bioscientifica Ltd. 
increased in IGF1-treated HMCs compared with the control (Fig. 5). Similar stimulation was observed if the IGF1 was complexed to wild-type IGF BP-4 but not if complexed to proteolytically resistant IGF BP-4.

\section{Discussion}

The major new findings in this study are (1) PAPP-A is expressed by normal human mesangial cells in vitro; (2) of the DN factors tested, the most potent stimulator of PAPP-A expression was IL-1 $\beta$; and (3) IL1 $\beta$ also significantly stimulated the expression of IGF BP-1. These novel findings, as well as the comprehensive analysis of IGF system regulation in HMCs, suggest mechanisms by which inflammatory states such as DN can influence IGF1 activity in the kidney. This interactive model is presented in Fig. 6 and discussed in this section.

We have shown that PAPP-A is not only expressed and secreted by human mesangial cells but also cell

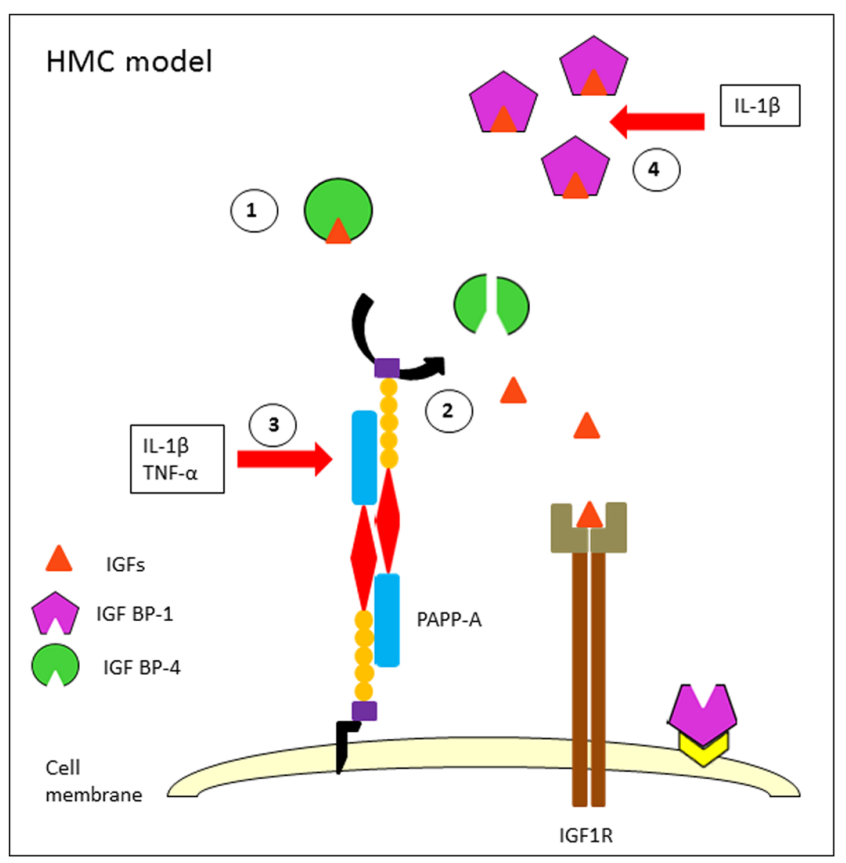

Figure 6

Regulation of IGF bioavailability by PAPP-A in HMC. (1) In the absence of PAPP-A, IGFs bound to IGF BP-4 are unable to interact with the IGF1R; (2) proteolytically active PAPP-A (represented as a modular head-to-tail homodimer (Boldt \& Conover 2007)) binds to cell-surface proteoglycans (Laursen et al. 2002). Cleavage of IGF BP-4 by PAPP-A leads to the liberation of IGFs, which is then able to activate the IGF1R; (3) macrophage-derived IL $1 \beta$ and TNF- $\alpha$ stimulation of HMCs leads to increased expression and secretion of PAPP-A, increased cleavage of IGF BP-4 and, therefore, more bioavailable IGF; (4) IL1 $\beta$ leads to increased IGF BP-1, which may act as an additional reservoir of IGFs located in the interstitial environment or cell membrane associated. associated and biologically active. This is important because PAPP-A (the only known physiological IGF BP-4 protease) produced by HMCs can serve to enhance the local bioavailability of IGF1 within the glomerulus. Stimulation of HMCs with IGF1 in vitro has been shown to increase mesangial cell proliferation and the production of extracellular matrix components (Moran et al. 1991, Feld et al. 1995, Schreiber et al. 1995, Pricci et al. 1996). Within the glomerulus, mesangial cells interact with other cells such as the podocyte, endothelium and inflammatory cells. Although no appreciable IGFs were detected in HMC-conditioned media, the presence and activation of the IGF1R indicate that HMCs are primed to respond to IGF1 in a paracrine or endocrine manner. Indeed, podocytes were shown to produce IGFs (Hale et al. 2013), especially IGF2. The seeming discrepancy in the detection IGF1, compared with other studies, may be explained by the use of different detection assays (radioimmunoassay vs ELISA), conditioned media concentrations, and cell type (murine vs human).

Although we did not see a direct effect of AGE or high glucose on HMC PAPP-A production, there is accumulating evidence to suggest that inflammation, as a result of metabolic and hemodynamic factors consequent to diabetes, plays a crucial role in the development of DN. Inflammatory cytokines, likely produced by local macrophages and other cells intrinsic to the kidney (Navarro-Gonzalez et al. 2011, Barutta et al. 2015), have a role in the pathogenesis of DN. How these growth factors and inflammatory cytokines interact and contribute to glomerular pathology and therefore the development of diabetic nephropathy, as well as other inflammatory glomerular pathologies, is not fully understood. We propose that one possible mechanism is through an increase in PAPP-A. Indeed, stimulation of HMCs with IL1 $\beta$ or TNF- $\alpha$ led to an increased expression and secretion of proteolytically active PAPP-A, as is shown in other cell types (Ortiz et al. 2003, Conover et al. 2006, Davidge-Pitts et al. 2014). However, the effect of different inflammatory cytokines on PAPP-A expression and secretion appears to be cell-type specific. TGF- $\beta$ and IL6 are shown to be potent stimulators of PAPP-A in human osteoblasts and human coronary artery smooth muscle cells, respectively (Ortiz et al. 2003, Conover et al. 2006). In HMCs, TGF- $\beta$ and IL6 did not lead to a significant increase in PAPP-A expression.

However, IGF1 is also regulated by IGF BPs which may inhibit or enhance IGF1 activity. IGF BP expression changes temporally and spatially during human fetal nephrogenesis likely modulating IGF1 effects during renal development (Matsell et al. 1994). Under basal

Published by Bioscientifica Ltd 
conditions, HMCs expressed all 6 IGF BPs, as has been previously reported (Grellier et al. 1996). Interestingly, IGF BP-1, which is primarily produced by the liver under negative regulation by insulin (Holly \& Perks 2006), is clearly expressed and produced by HMCs. We demonstrate for the first time that IGF BP-1 is increased by IL1 $\beta$ stimulation. It is hypothesized that IGF BP-1 may lead to the accumulation of IGF1 in the kidney. In the kidney of rats with STZ-induced diabetes, IGF BP-1mRNA expression was increased with an increase in IGF1 protein, but without an increase in IGF1 expression (Landau et al. 1995, Segev et al. 1997, van Neck et al. 1997, Bach et al. 2000). Mice, transgenic for IGF BP-1, developed glomerulosclerosis, the severity of which correlated with IGF BP-1 levels and was associated with the expansion of the mesangium (Doublier et al. 2000). Unlike the concordant increase of PAPP-A expression by IL1 $\beta$ and TNF- $\alpha$, HMCs treated with TNF- $\alpha$ led to a decrease in IGF BP-1. The significance of the divergent effect of IL1 $\beta$ and TNF- $\alpha$ on IGF BP-1 is not clear.

Under basal conditions, there is a relative abundance of IGF BP-5 in conditioned medium, as measured using ELISA, compared with IGF BP-1 and IGF BP-4. However, after the stimulation of HMCs with IL1 $\beta$, TGF- $\beta$ and TNF- $\alpha$, IGF BP-5 expression and production are significantly reduced. Although IGF BP-5, as quantified by ELISA, appeared to be the most abundant under basal conditions, it is not known whether this represents the intact or fragmented binding protein as PAPP-A is known to cleave IGF BP-5 in the absence of as well as in the presence of IGF1. It is hypothesized that there is sequential proteolysis of IGF BPs by PAPP-A (IGF BP-5 followed by IGF BP-4) which results in the delivery of IGF1 to its receptor (Laursen et al. 2007). Despite this relative abundance, $\left[{ }^{3} \mathrm{H}\right]$-thymidine incorporation was increased after IGF1 stimulation, and proteolysis was enhanced by IL1 $\beta$ and TNF- $\alpha$ in the presence of IGF2 compared with control.

IL1 $\beta$ and TNF- $\alpha$ had no effect or had inhibitory effects on IGF BP-2 to -6 , which could lead to reduced overall binding capacity for IGFs. In the case of TGF- $\beta$, there was a general inhibitory effect on IGF BP expression, except for IGF BP-3. Stimulation of HMCs with TGF- $\beta$ led to a significant increase in IGF BP-3, as reported previously (Grellier et al. 1996). TGF- $\beta$ is a major player in mesangial expansion in DN. It is unclear how an increase in IGF BP-3 may contribute to DN. In adolescents with type I diabetes and microalbuminuria, urinary IGF BP-3 was increased compared with those without microalbuminuria (Spagnoli et al. 1999). In addition, urinary IGF BP-3 fragments are increased in patients with DN compared with those without suggesting an increase in renal IGF BP-3, IGF BP-3 proteolysis and, therefore, free IGF1 (Shinada et al. 2000). It is possible that IGF BP-3 may also have IGF1-independent effects, such as HMC apoptosis (Verzola et al. 2001).

We did not see any effect of high glucose or AGE on PAPP-A levels or other IGF system components after stimulation. It is possible that the frequency or duration of exposure was inadequate (up to 4 weeks for high glucose and 7 days for AGEs). Alternatively, chronic hyperglycemia or AGEs may affect HMCs indirectly through the induction of inflammatory cytokines such as IL1 $\beta$ or TNF- $\alpha$. Therefore, we have demonstrated the effect of inflammation on the IGF system, in particular PAPP-A. Although inflammation is accepted to play a role in the pathophysiology of $\mathrm{DN}$, this has greater clinical implications as PAPP-A may play a role in other inflammatory conditions involving the glomerulus. It is important to point out that the aggregate effect of IGF1 in DN is dependent on the influence of several factors including the relative abundance of IGF BPs and IGF BP proteases, which in turn is regulated by inflammatory cytokines. Furthermore, the glomerulus is composed of several other cell types, which are likely to possess unique responses to similar stimuli. Therefore, corroborating in vitro with in vivo findings remains crucial, going forward in determining the clinical significance of these findings.

Studies on HMCs in culture allow us to understand the effects that individual interventions have on the IGF system allowing for the identification of possible therapeutic targets. In particular, this is the first time that PAPP-A has been shown to be expressed and produced by HMCs and regulated by proinflammatory cytokines. However, a different approach will be required to fully understand the physiology and pathophysiology of interactive function in the kidney. In addition, complete inhibition of PAPP-A proteolysis is possible with a targeted mAb-PAPP-A, as recently published for ovarian cancer (Becker et al. 2015), atherosclerosis (Conover et al. 2016) and as presented in Fig. 4 as proof-of-concept for mesangial cells. Therefore, PAPP-A may represent a novel therapeutic target in inflammatory conditions of the glomerulus and further clarification of the role it plays in DN is warranted.

\section{Declaration of interest}

The authors declare that there is no conflict of interest that could be perceived as prejudicing the impartiality of the research reported.

Published by Bioscientifica Ltd 


\section{Funding}

This work was supported by grants from the Ted Nash Long Life Foundation and the National Center for Advancing Translational Sciences (UL1 TR000135).

\section{Author contribution statement}

All authors contributed to conception, design, acquisition of data, analysis and interpretation of data, and have participated in drafting the manuscript.

\section{References}

Abboud HE 2012 Mesangial cell biology. Experimental Cell Research 318 979-985. (doi:10.1016/j.yexcr.2012.02.025)

ADA 2014 Diagnosis and classification of diabetes mellitus. Diabetes Care 37 S81-S90. (doi:10.2337/dc14-s081)

An Y, Xu F, Le W, Ge Y, Zhou M, Chen H, Zeng C, Zhang H \& Liu Z 2015 Renal histologic changes and the outcome in patients with diabetic nephropathy. Nephrology, Dialysis, Transplantation 30 257-266. (doi:10.1093/ndt/gfu250)

Bach LA, Dean R, Youssef S \& Cooper ME 2000 Aminoguanidine ameliorates changes in the IGF system in experimental diabetic nephropathy. Nephrology, Dialysis, Transplantation 15 347-354. (doi:10.1093/ndt/15.3.347)

Bale LK, Chakraborty S \& Conover CA 2014 Inducible reduction in pregnancy-associated plasma protein-A gene expression inhibits established atherosclerotic plaque progression in mice. Endocrinology 155 1184-1187. (doi:10.1210/en.2013-2110)

Barutta F, Bruno G, Grimaldi S \& Gruden G 2015 Inflammation in diabetic nephropathy: moving toward clinical biomarkers and targets for treatment. Endocrine 48 730-742. (doi:10.1007/s12020014-0437-1)

Becker MA, Haluska P Jr, Bale LK, Oxvig C \& Conover CA 2015 A novel neutralizing antibody targeting pregnancy-associated plasma protein-a inhibits ovarian cancer growth and ascites accumulation in patient mouse tumorgrafts. Molecular Cancer Therapeutics 14 973-981. (doi:10.1158/1535-7163.MCT-14-0880)

Boldt HB \& Conover CA 2007 Pregnancy-associated plasma protein-A (PAPP-A): a local regulator of IGF bioavailability through cleavage of IGFBPs. Growth Hormone \& IGF Research 17 10-18. (doi:10.1016/ j.ghir.2006.11.003)

Conover CA, Kiefer MC \& Zapf J 1993 Posttranslational regulation of insulin-like growth factor binding protein-4 in normal and transformed human fibroblasts. Insulin-like growth factor dependence and biological studies. Journal of Clinical Investigation 91 1129-1137. (doi:10.1172/JCI116272)

Conover CA, Bale LK, Harrington SC, Resch ZT, Overgaard MT \& Oxvig C 2006 Cytokine stimulation of pregnancy-associated plasma protein A expression in human coronary artery smooth muscle cells: inhibition by resveratrol. American Journal of Physiology: Cell Physiology 290 C183-C188. (doi:10.1152/ajpcell.00199.2005)

Conover CA, Harrington SC, Bale LK \& Oxvig C 2007 Surface association of pregnancy-associated plasma protein-A accounts for its colocalization with activated macrophages. American Journal of Physiology: Heart and Circulatory Physiology 292 H994-H1000. (doi:10.1152/ajpheart.00798.2006)

Conover CA, Bale LK, Mader JR, Mason MA, Keenan KP \& Marler RJ 2010 Longevity and age-related pathology of mice deficient in pregnancy-associated plasma protein-A. Journals of Gerontology. Series A, Biological Sciences and Medical Sciences 65 590-599. (doi:10.1093/gerona/glq032)
Conover CA, Bale LK \& Oxvig C 2016 Targeted inhibition of pregnancyassociated plasma protein-A activity reduces atherosclerotic plaque burden in mice. Journal of Cardiovascular Translational Research 9 77-79. (doi:10.1007/s12265-015-9666-9)

Davidge-Pitts C, Escande CJ \& Conover CA 2014 Preferential expression of PAPPA in human preadipocytes from omental fat. Journal of Endocrinology 222 87-97. (doi:10.1530/JOE-13-0610)

Doublier S, Seurin D, Fouqueray B, Verpont MC, Callard P, Striker LJ, Striker GE, Binoux M \& Baud L 2000 Glomerulosclerosis in mice transgenic for human insulin-like growth factor-binding protein-1. Kidney International 57 2299-2307. (doi:10.1046/j.15231755.2000.00090.x)

Durham SK, Riggs BL \& Conover CA 1994 The insulin-like growth factor-binding protein-4 (IGFBP-4)-IGFBP-4 protease system in normal human osteoblast-like cells: regulation by transforming growth factor-beta. Journal of Clinical Endocrinology and Metabolism 79 1752-1758. (doi:10.1210/jcem.79.6.7527411)

Feld SM, Hirschberg R, Artishevsky A, Nast C \& Adler SG 1995 Insulin-like growth factor I induces mesangial proliferation and increases mRNA and secretion of collagen. Kidney International 48 45-51. (doi:10.1038/ ki.1995.265)

Fioretto P \& Mauer M 2007 Histopathology of diabetic nephropathy. Seminars in Nephrology 27 195-207. (doi:10.1016/j.semnephrol. 2007.01.012)

Grellier P, Sabbah M, Fouqueray B, Woodruff K, Yee D, Abboud HE \& Abboud SL 1996 Characterization of insulin-like growth factor binding proteins and regulation of IGFBP3 in human mesangial cells. Kidney International 49 1071-1078. (doi:10.1038/ ki.1996.156)

Hale LJ, Welsh GI, Perks CM, Hurcombe JA, Moore S, Hers I, Saleem MA, Mathieson PW, Murphy AJ, Jeansson M, et al. 2013 Insulin-like growth factor-II is produced by, signals to and is an important survival factor for the mature podocyte in man and mouse. Journal of Pathology 230 95-106. (doi:10.1002/path.4165)

Harstad SL \& Conover CA 2014 Tissue-specific changes in pregnancy associated plasma protein-A expression with age in mice. Experimental Gerontology 57 13-17. (doi:10.1016/j.exger.2014.04.011)

Hirschberg R \& Adler S 1998 Insulin-like growth factor system and the kidney: physiology, pathophysiology, and therapeutic implications. American Journal of Kidney Diseases 31 901-919. (doi:10.1053/ ajkd.1998.v31.pm9631833)

Holly J \& Perks C 2006 The role of insulin-like growth factor binding proteins. Neuroendocrinology 83 154-160. (doi:10.1159/000095523)

Kamenicky P, Mazziotti G, Lombes M, Giustina A \& Chanson P 2014 Growth hormone, insulin-like growth factor-1, and the kidney: pathophysiological and clinical implications. Endocrine Reviews $\mathbf{3 5}$ 234-281. (doi:10.1210/er.2013-1071)

Landau D, Chin E, Bondy C, Domene H, Roberts CT Jr, Gronbaek H, Flyvbjerg A \& LeRoith D 1995 Expression of insulin-like growth factor binding proteins in the rat kidney: effects of long-term diabetes. Endocrinology 136 1835-1842. (doi:10.1210/en.136.5.1835)

Laursen LS, Overgaard MT, Weyer K, Boldt HB, Ebbesen P, Christiansen M, Sottrup-Jensen L, Giudice LC \& Oxvig C 2002 Cell surface targeting of pregnancy-associated plasma protein A proteolytic activity. Reversible adhesion is mediated by two neighboring short consensus repeats. Journal of Biological Chemistry 277 47225-47234. (doi:10.1074/jbc. M209155200)

Laursen LS, Kjaer-Sorensen K, Andersen MH \& Oxvig C 2007 Regulation of insulin-like growth factor (IGF) bioactivity by sequential proteolytic cleavage of IGF binding protein-4 and -5. Molecular Endocrinology 21 1246-1257. (doi:10.1210/me.2006-0522)

Lawrence JB, Oxvig C, Overgaard MT, Sottrup-Jensen L, Gleich GJ, Hays LG, Yates JR 3rd \& Conover CA 1999 The insulin-like growth factor (IGF)-dependent IGF binding protein-4 protease secreted by human fibroblasts is pregnancy-associated plasma protein-A. PNAS 96 3149-3153. (doi:10.1073/pnas.96.6.3149) 
Mader JR, Resch ZT, McLean GR, Mikkelsen JH, Oxvig C, Marler RJ \& Conover CA 2013 Mice deficient in PAPP-A show resistance to the development of diabetic nephropathy. Journal of Endocrinology 219 51-58. (doi:10.1530/JOE-13-0167)

Maezawa Y, Takemoto M \& Yokote K 2015 Cell biology of diabetic nephropathy: roles of endothelial cells, tubulointerstitial cells and podocytes. Journal of Diabetes Investigation 6 3-15. (doi:10.1111/ jdi.12255)

Matsell DG, Delhanty PJ, Stepaniuk O, Goodyear C \& Han VK 1994 Expression of insulin-like growth factor and binding protein genes during nephrogenesis. Kidney International 46 1031-1042. (doi:10.1038/ki.1994.364)

Mauer SM, Steffes MW, Ellis EN, Sutherland DE, Brown DM \& Goetz FC 1984 Structural-functional relationships in diabetic nephropathy. Journal of Clinical Investigation 74 1143-1155. (doi:10.1172/ JCI111523)

Mikkelsen JH, Resch ZT, Kalra B, Savjani G, Kumar A, Conover CA \& Oxvig C 2014 Indirect targeting of IGF receptor signaling in vivo by substrate-selective inhibition of PAPP-A proteolytic activity. Oncotarget 5 1014-1025. (doi:10.18632/oncotarget.1629)

Moran A, Brown DM, Kim Y \& Klein DJ 1991 Effects of IGF1 and glucose on protein and proteoglycan synthesis by human fetal mesangial cells in culture. Diabetes 40 1346-1354. (doi:10.2337/diab.40.10.1346)

Navarro-Gonzalez JF, Mora-Fernandez C, Muros de Fuentes M \& Garcia-Perez J 2011 Inflammatory molecules and pathways in the pathogenesis of diabetic nephropathy. Nature Reviews. Nephrology 7 327-340. (doi:10.1038/nrneph.2011.51)

Ortiz CO, Chen BK, Bale LK, Overgaard MT, Oxvig C \& Conover CA 2003 Transforming growth factor-beta regulation of the insulin-like growth factor binding protein-4 protease system in cultured human osteoblasts. Journal of Bone and Mineral Research 18 1066-1072. (doi:10.1359/jbmr.2003.18.6.1066)

Pricci F, Pugliese G, Romano G, Romeo G, Locuratolo N, Pugliese F, Mene P, Galli G, Casini A, Rotella CM, et al. 1996 Insulin-like growth factors I and II stimulate extracellular matrix production in human glomerular mesangial cells. Comparison with transforming growth factor-beta. Endocrinology 137 879-885. (doi:10.1210/en.137.3.879)
Schreiber BD, Hughes ML \& Groggel GC 1995 Insulin-like growth factor-1 stimulates production of mesangial cell matrix components. Clinical Nephrology 43 368-374.

Segev Y, Landau D, Marbach M, Shehadeh N, Flyvbjerg A \& Phillip M 1997 Renal hypertrophy in hyperglycemic non-obese diabetic mice is associated with persistent renal accumulation of insulin-like growth factor I. Journal of the American Society of Nephrology 8 436-444.

Shinada M, Akdeniz A, Panagiotopoulos S, Jerums G \& Bach LA 2000 Proteolysis of insulin-like growth factor-binding protein-3 is increased in urine from patients with diabetic nephropathy. Journal of Clinical Endocrinology and Metabolism 85 1163-1169. (doi:10.1210/ jc.85.3.1163)

Spagnoli A, Chiarelli F, Vorwerk P, Boscherini B \& Rosenfeld RG 1999 Evaluation of the components of insulin-like growth factor (IGF)-IGF binding protein (IGFBP) system in adolescents with type 1 diabetes and persistent microalbuminuria: relationship with increased urinary excretion of IGFBP-3 18 kD N-terminal fragment. Clinical Endocrinology 51 587-596. (doi:10.1046/j.13652265.1999.00842.x)

Steffes MW, Osterby R, Chavers B \& Mauer SM 1989 Mesangial expansion as a central mechanism for loss of kidney function in diabetic patients. Diabetes 38 1077-1081. (doi:10.2337/diab.38.9.1077)

Tervaert TW, Mooyaart AL, Amann K, Cohen AH, Cook HT, Drachenberg CB, Ferrario F, Fogo AB, Haas M, de Heer E, et al. 2010 Pathologic classification of diabetic nephropathy. Journal of the American Society of Nephrology 21 556-563. (doi:10.1681/ ASN.2010010010)

van Neck JW, Flyvbjerg A, Schuller AG, Rosato RR, Groffen C, van Kleffens M, Lindenbergh-Kortleve D, Dorup I \& Drop SL 1997 IGF, type I IGF receptor and IGF-binding protein mRNA expression in kidney and liver of potassium-depleted and normal rats infused with IGF1. Journal of Molecular Endocrinology 19 59-66. (doi:10.1677/ jme.0.0190059)

Verzola D, Villaggio B, Berruti V, Gandolfo MT, Deferrari G \& Garibotto G 2001 Apoptosis induced by serum withdrawal in human mesangial cells. Role of IGFBP-3. Experimental Nephrology 9 366-371. (doi:10.1159/000052634)

Received in final form 8 August 2016

Accepted 12 August 2016

Accepted Preprint published online 12 August 2016
() 2016 Society for Endocrinology Printed in Great Britain 